\title{
Impact of air transport on climate change
}

\section{Impacto del transporte aéreo en el cambio climático}

DOI: $10.46932 / \mathrm{sfjdv2n3-018}$

Received in: May 1st, 2021

Accepted in: Jun 30th, 2021

PhD. Juan Carlos Garmendia Mora

Institución Universitaria Politécnico Grancolombiano

Facultad de Negocios, Gestión y Sostenibilidad

Bogotá, D.C., Colombia.

Tel.: 57-7-7455555, Ext. 1348

E-mail: jgarmendia@poligran.edu.co / juangarmendia@yahoo.com

PhD. Ender José Barrientos Monsalve

Fundación de Estudios Superiores Comfanorte, Cúcuta, Colombia

Tel.: 57-321-2249156

E-mail: enderjbm@gmail.com

PhD. Lloyd Herbert Morris Molina

Universidad Católica de Pereira, Pereira, Colombia

Tel.: 57-321-3627427

E-mail: lloyd.morris@ucp.edu.com

\begin{abstract}
Air transport has been a transcendental activity for human development, but it has also contributed to one of the main problems that the planet has: climate change. The objective of this article is to present a state of the art of the impact that air transport has on climate change and what is being done to mitigate it. To this end, a thorough review was made of the information contained in each of the main entities or actors involved in organizing, regulating, proposing, developing, or operating the actions or innovations that must be executed to meet the proposed goals. ICAO and IATA are the global organizations that have led the baton in these processes, but we must also highlight the inclusion of many airlines, aircraft manufacturers, engine manufacturers, fuel manufacturers, airport operators and different organizations research and development that are contributing ideas for the reversal of this climate change, which leaves the hopeful idea that the goals can be met.
\end{abstract}

Keywords: air transport, climate change, airlines, biofuel.

\section{RESUMEN}

El transporte aéreo ha sido una actividad trascendental para el desarrollo humano, pero también ha contribuido a uno de los principales problemas que tiene el planeta: el cambio climático. Se tiene por objetivo presentar un estado del arte del impacto que tiene el transporte aéreo en el cambio climático y qué se está haciendo para mitigarlo. Para ello se realizó una revisión concienzuda de la información que contiene cada uno de los principales entes o actores involucrados en organizar, regular, proponer, desarrollar u operar las acciones o las innovaciones que se deben ejecutar para cumplir las metas propuestas. La OACI y la IATA son las organizaciones mundiales que han llevado la batuta en estos procesos, pero también hay que resaltar la inclusión de un gran número de aerolíneas, fabricantes de 
aeronaves, fabricantes de motores, fabricantes de combustibles, operadores aeroportuarios y distintas organizaciones de investigación y desarrollo que están aportando ideas para la reversión de este cambio climático, lo cual deja la idea esperanzadora de que las metas se pueden cumplir.

Palabras clave: transporte aéreo, cambio climático, aerolíneas, biocombustible.

\section{INTRODUCTION}

Since air transportation became popular in the world, tourism also became more widespread, even more so when tourism activity was carried out by means of long-distance travel. Prior to air transportation, the displacement of human beings for leisure and recreational activities was a privilege of aristocrats, bourgeois and people with great purchasing power, these activities were practically forbidden for any individual or working class family. Tourism, in principle a phenomenon of minorities, of elites with a high economic power, becomes a mass phenomenon when the machine leaves more free time and, at the same time, says Velani quoted by Cordero (1970) that commercial aviation has a decisive influence on the rapid growth of tourist activity that makes that in seven years, from 1958 to 1965 , the number of travelers transported multiplied by 10 .

Air transport offers a series of advantages to society, according to Alonso and Benito (2012), this transport system privileges human beings with speed, job creation, competitiveness, territorial cohesion, connectivity, technological spin-off, scientific and cultural exchange, etc., in addition to being the safest mode of transport. The environmental impact is practically the only relevant negative element associated with this activity and, therefore, major efforts must be made to control and mitigate it.

In different latitudes, air transport is a key segment for tourism, a strategic element of the economy due to its contribution to wealth and employment. In Spain, for example, Aeropuertos Españoles y Navegación Aérea (AENA) is the world's leading airport operator. This company recalls that Spain, which is the first destination in the world in vacation tourism, the second by tourist expenditure and by number of tourists, received 82.8 million international tourists in 2018 , of which more than $80 \%$ of its travelers arrived by air (AENA, 2019).

Related to the above, Vogeler (2012) comments that:

Air transportation is a central component of tourism development. Around $50 \%$ of international tourism arrivals are produced by air, an even more important percentage for destinations in Central America (55\%), South America (54\%), and especially for the Caribbean islands (98\%). The development and competitiveness of air transport is therefore absolutely critical to the progress of tourism in Latin America, just as the growth of the airline industry in the region depends to a large extent on the progress of the tourism sector. 
Air transportation is a very organized activity worldwide, due to several factors, among which are its economic importance and the need to be an operation with high safety standards. This is why there is a United Nations organization exclusively dedicated to coordinate and direct civil aviation, the International Civil Aviation Organization (ICAO), of which there are 192 countries signatories of its founding act, the Chicago Convention of 1944, and which have continued to act as active members for the better development of aviation in the world.

Practically in parallel to the creation of ICAO by the governments of the world, the International Air Transport Association (IATA) was established as a result of the grouping of air transport companies; it currently has 290 airlines as permanent members, which are located in 120 countries. This institution has been fundamental in the organization and development of today's air transportation system.

It is precisely these two institutions that have taken the initiative to bring air transport operations into line with international environmental standards. Various studies indicate that tourism contributes 5 $\%$ of global CO2 emissions, of which $40 \%$ come from air transport and $20 \%$ from hotels and other types of accommodation. The remaining $40 \%$ of these emissions are related to other types of transport (cruises, vehicles, rail, etc.) and recreational services associated with tourism. (UNWTO, 2017).

In addition to the above, Liu (2017) predicts that the 2016 air traffic volume, both in terms of flights and passengers, will double in a span of only 15 years. Air transport is the single activity of the tourism operation that pollutes the most and impacts climate change, so it is necessary to review what is being done in this sector to counteract and reduce its carbon footprint.

\section{THEORETICAL ELEMENTS}

\subsection{ENVIRONMENTAL IMPACT}

Garmendia, Salvador, Crespo and Garmendia (2005) state that "environmental impact is the alteration of the quality of the environment produced by a human activity" (p. 18). They add that firstly, the specific cause of the impact must be considered and secondly, the impact must be quantified, i.e., a positive or negative evaluation must be made. In this sense, Gómez and Gómez (2013) comment on the relationship between two concepts: development and the environment. Every day there is more environmental awareness and sensitivity, which has forced a rethinking of the economic concept of development, adding qualitative elements such as quality of life, which would include the quality of the air we breathe, or the levels of sonic pollution, for example.

There are environmental problems on a local scale, of which there are some that are recurrent in different latitudes, which is why they have become environmental problems on a global scale, affecting all human beings to a greater or lesser degree. Among these major problems on a global scale is climate 
change, which according to Garmendia, Salvador, Crespo and Garmendia (2005) consists of an increase in the average temperature of the planet, mainly due to the emission of Greenhouse Gases (GHG), among which is CO2, which is emitted by aircraft engines (Martelli, 2020).

One of the most widely used tools to measure the amount of greenhouse gases (GHG) is the Carbon Footprint (CF). These gases prevent all the solar radiation that is reflected by the earth from leaving, generating an increase in the temperature below them (Espíndola and Valderrama, 2012). Schneider and Samaniego (2012) complement this by mentioning that the carbon footprint refers to the tons of GHG carbon dioxide equivalent generated from the consumption of fossil fuels.

On that, a group of experts on climate change of the United Nations Organization (UN, 2015) has warned of the danger posed by this threat and has expressed the urgency to seek solutions as soon as possible. GHG emissions continue to rise and, at the current rate, the global average temperature could increase by more than three degrees Celsius in the 21 st century. The effects of climate change are already being felt on a daily basis, such as rising sea levels, melting glaciers and other more intense phenomena. Sustainability plays an important role in the work to counteract climate change.

Zarta (2018) reports that "although they have common edges, sustainable relates to the existing harmony between the economic, social, environmental with the value system, while sustainable considers each of these subsystems separately." Sustainability is related to the finite resources of the planet, the brutal growth of the population, pollution, the need to be economically viable, which is why the search for this balance between the environmental, economic and social aspects is a task that requires a lot of effort from the different countries of the world, with each of their institutions and companies.

\subsection{ENVIRONMENTAL IMPACT OF AIR TRANSPORTATION}

Aviation plays an important role in the economic development of many countries, but it is also true that it is an activity that pollutes the environment, as shown in Figure 1, on a study developed by the European Environment Agency (2019), carbon dioxide emissions from air transport are higher than any other means of transport, this when normalized according to the number of passengers and kilometers traveled; when comparing, for example, air transport with land transport with private vehicles, airplanes emit an average of 285 grams of $\mathrm{CO} 2$ per passenger and kilometer, while the land vehicle emits an average of 104 grams of $\mathrm{CO} 2$ per passenger and kilometer, i.e., the car emits only $36.5 \%$ of what an average aircraft emits. 
Figure 1: Carbon dioxide emissions from passenger transport.

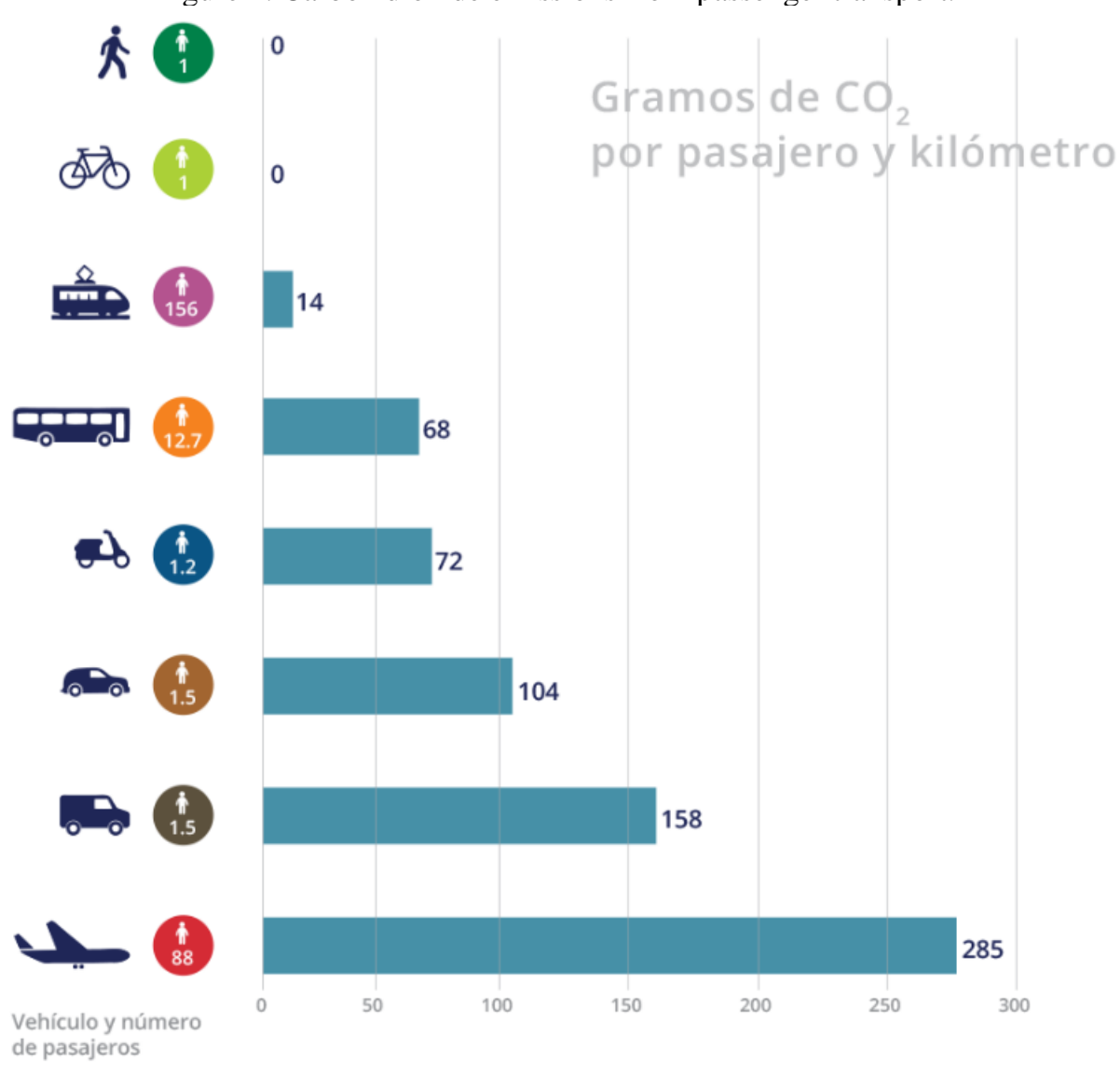

Source: European Environment Agency (2019)

Another of the effects on the environment is acoustics, which is generated by practically all activities carried out by human beings. As for transportation, of all the known modes, air transport is the one that generates the greatest amount of acoustic damage, and has an even greater influence, taking into consideration that the greatest acoustic load is generated at airports, which are normally surrounded by urban areas, so that these areas are seriously affected (Yanitelli et al., 2001). (Yanitelli et al., 2001).

There is another very visible phenomenon produced by aircraft during their flights: the trails they leave in the sky after their flight. These condensation trails, called contrails, appear after the passage of aircraft; Bock and Burkhardt of the German Aerospace Center, cited by Criado (2019) have projected the impact on the climate of these contrails from 2006 to 2050. The work concludes that these artificial cirrus clouds contribute more to climate change than the greenhouse gases (GHGs) themselves emitted by aircraft engines and that their contribution to global warming will triple by 2050 compared to 2006 . Trails are short-lived in the sky while $\mathrm{CO} 2$ remains for centuries, so if air traffic is reduced or the trails it produces are reduced, the climate benefit will be seen quickly.

Another important institution that investigates the environmental affectations of various human activities is Atmosfair, who observe active climate protection; according to Street (2018), the atmosfair 
airline index annually compares and ranks the world's 190 largest airlines according to their climate efficiency, i.e. $\mathrm{CO}_{2}$ emissions per transport service. The calculation of $\mathrm{CO}_{2}$ emissions takes into consideration factors such as aircraft type, engines, winglets, number of seats, cargo space and capacity utilization.

Figure 2: Climate impact of flights compared to other human activities.

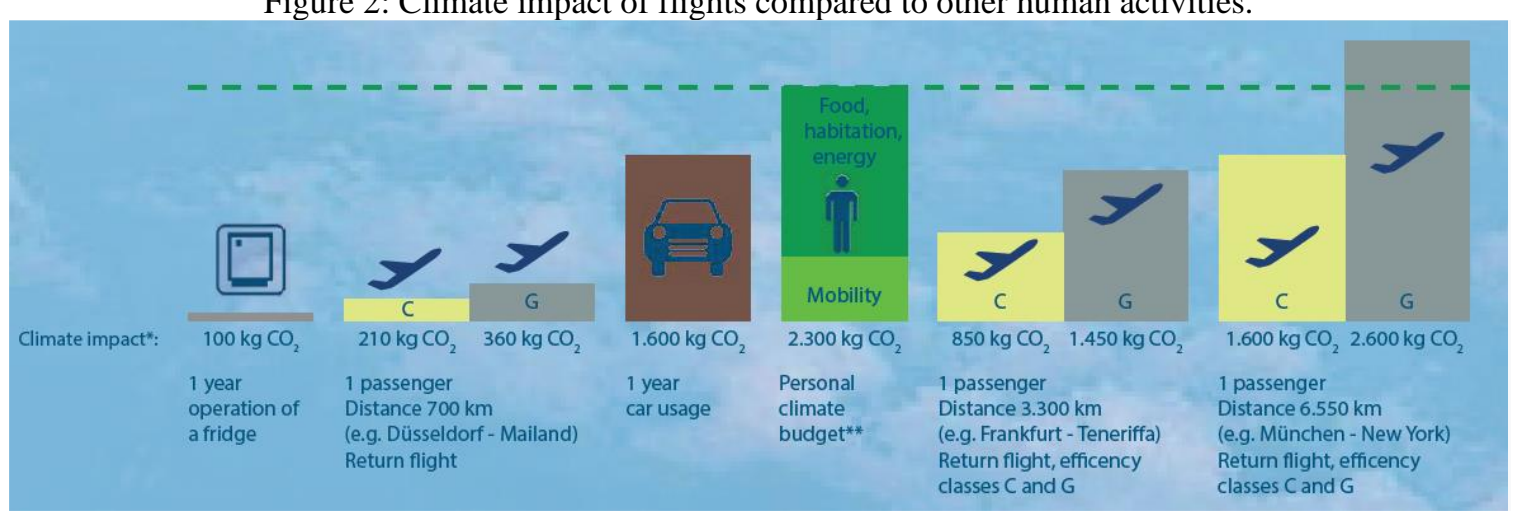

Source: Atmosfair (2018)

Figure 2 shows the impact on the climate caused by different types of flights, according to the distance traveled and compared to other human activities. For example, the operation of a household refrigerator for one year emits 100 kilograms $(\mathrm{kg})$ of $\mathrm{CO} 2$, while a 700 kilometer $(\mathrm{km})$ round-trip flight can emit $210 \mathrm{~kg}$ of $\mathrm{CO} 2$ for each passenger, i.e., more than double the amount of pollution. A year's use of a private vehicle generates an average of $1,600 \mathrm{~kg}$ of $\mathrm{CO} 2$, while a 3,300 km round-trip flight generates $850 \mathrm{~kg}$ of $\mathrm{CO} 2$ per passenger. From these data provided by Atmosfair, it is possible to infer what is written in Table 1:

Table 1: CO2 emissions per kilometer driven

\begin{tabular}{ccc}
$\begin{array}{c}\text { Flight } \\
\text { distance }(\mathbf{k m})\end{array}$ & $\begin{array}{c}\mathbf{C O}_{2} \text { emitted } \\
(\mathbf{k g})\end{array}$ & $\mathbf{k g}$ of CO2 / km \\
\hline 1400 & 210 & 0,15 \\
6600 & 850 & 0,1288 \\
13100 & 1600 & 0,1221
\end{tabular}

Source: own elaboration based on data from Atmosfair (2018).

It is true that the number of kilograms of $\mathrm{CO} 2$ emitted into the atmosphere per kilometer flown decreases as flights become longer, but the net values increase considerably. This is one of the most criticized aspects of air transport; some environmental organizations propose the elimination of these long-haul flights because they are the ones that emit the most kilograms of CO2 into the atmosphere, but unfortunately they are the routes that have the fewest substitute options, precisely because of the long distances involved. It is possible that short-haul flights can be substituted by other transportation options such as train or bus because the travel time between one and the other is not so significant, but as the 
distance increases, the difference in time between air travel and the other options also increases, leaving air travel as the only real and practical option.

\section{PROPOSALS AND ADVANCES TO REDUCE ENVIRONMENTAL IMPACT}

In air transportation there are two fundamental elements involved in the operation: airplanes and airports. Both the vehicles used to make the transfer, as well as the departure and arrival sites, are polluting factors that generate negative impacts on the climate; that is why both were taken into account for the proposals that have been made in order to reduce or mitigate the impact of air operations on climate change.

Work in this area has been ongoing for decades, but 2008 was a turning point for the strategy to be followed by the entities involved. In this year, the ICAO High Level Meeting on International Aviation and Climate Change (2010) was held, in which several agreements were reached, among the most important of which are:

a) A global goal of $2 \%$ annual fuel efficiency improvement until 2050, in addition to the pursuit of carbon neutral growth and emission reductions;

b) The preparation of a global CO2 standard for aircraft and the proposal of operational improvements to reduce aviation emissions;

c) Assisting developing countries and facilitating access to financial resources, technology transfer and capacity building.

All entities involved in aviation operations (aircraft manufacturers, engine manufacturers, airlines, airports, fuel manufacturers, governments) have been actively working to meet these strategic goals proposed by ICAO, and to some extent also by IATA.

\subsection{THE AIRCRAFTS}

In today's world of air transportation there are two companies that are leaders in the manufacture of transport aircraft, the American Boeing and the European Airbus. Both have included in their strategic plans the design of more efficient and environmentally friendly aircraft. The new technologies being developed by Boeing will provide greater fuel efficiency, through the development of a sustainable biofuel for airplanes or working with communities globally on important environmental issues. (Boeing, 2019)

According to McElroy (2019), in 2006 there were different protests in the United Kingdom and other European countries, reproaching short-haul flights, showing that they were harmful to the environment. This, together with other elements, alerted aeronautical companies, and it was then that Boeing proposed a comprehensive environmental strategy, in which one of its main goals was to reduce 
carbon dioxide emissions by $80 \%$. Several events have taken place along this path, starting in 2008 with the flight from London to Amsterdam of a Virgin Atlantic 747-400 aircraft, using 20\% biofuel made from coconut oil and babassu. These test flights have been joined by other airlines such as Air New Zealand, Continental and Japan Airlines, in these cases with fuels derived from waste animal fat called HEFA, promoting recycling, involving different brands of engines such as CFM, Pratt \& Whitney and Rolls Royce. This biofuel was certified in 2011 for commercial use.

As part of this strategy, Boeing offers to cover the fuel costs for the first flight of each new aircraft delivered to its factory, as long as it includes biofuel. Most recently, in January 2019, Etihad Airways made its first flight from Abu Dhabi to Amsterdam with passengers, consuming biofuel.

In addition to what Boeing does and promotes, the aircraft manufacturing company Airbus spends more than $€ 3$ billion annually on research and development and holds approximately 37,000 patents worldwide (Airbus, 2019). This company collaborates with leading organizations and contributes to major initiatives on a European and international scale, as well as holding an International Organization for Standardization (ISO) 14001 environmental certification; these are practical standards for companies and organizations of all types seeking to manage their environmental responsibilities. Airbus was the first aircraft manufacturer with ISO 14001 certification for all its sites, products and services.

The growing fleet of A350 XWB aircraft is an example of Airbus' new technology: eco-efficient aircraft generation. Both variants - the A350-900 and its longer twin, the A350-1000 reduce fuel burn and emissions by $25 \%$ compared to the previous generation of aircraft. In addition to the design of more efficient aircraft, Airbus is immersed in the production of satellites that promote greater understanding of air pollution (Faury, 2019).

\subsection{THE ENGINES}

Two of the largest aircraft engine manufacturers are Pratt \& Whitney in the United States and Rolls Royce in Europe. In early 2008, Pratt \& Whitney began to make significant advances in more environmentally friendly engines, demonstrating the Geared Turbofan, which successfully operated using a combination of alternative fuels during ground testing. In 2009, a Pratt \& Whitney engine was on Japan Airlines' first test demonstration flight using biofuel. An Air China Boeing 747 aircraft powered by Pratt \& Whitney PW4000 engines completed a flight using a sustainable biofuel in October 2011. Importantly for the economics and viability of these developments, no modifications to the aircraft or engine were required for the biofuel. The flight was completed as part of the Cooperative Energy Program's Sustainable Biofuels program, led by Boeing and other industry members, including Honeywell and Pratt \& Whitney (Boeing, 2019). 
For more than 20 years, Pratt \& Whitney has made significant investments in technologies such as the Geared Turbofan engine and its family of fuels for Technology Advanced Low Nitrogen Oxide (TALON) technology. It has also advanced the design of the next generation of sustainable products, including the PW100, PW300, PW600 and PW800 engine families, and with engine enhancements including upgrades to the Advantage70 and V2500Select engines.

In partnership with NASA, Pratt \& Whitney developed the TALON family of burners that reduce nitrogen oxides (NOx), unburned hydrocarbons (UHC) and carbon monoxide (CO). Each gas is among several regulated pollutants that affect local air quality, and in the case of NOx, can also affect climate change.

Pratt \& Whitney then certified the TALON II combustor for use in the PW4158 and PW4168 engines that power Airbus A330 aircraft. The TALON II combustor is also in revenue service on the Airbus A318 aircraft powered by the PW6000 engine. When installed on the Airbus aircraft, PW4000 engines with TALON II combustors have reduced NOx emissions by 19 to $28 \%$, UHC emissions by $28 \%$, and $\mathrm{CO}$ emissions by approximately $6 \%$ compared to the initial production combustors. (Pratt\&Whitney, 2019).

In relation to this issue, as mentioned in the LEMCOTEC project (2017), the Advisory Council for Aviation Research and Innovation in Europe (ACARE) has determined challenging targets, even more challenging than those proposed by ICAO, to be met by 2020 and 2050. This includes the development of technologies and procedures to: reduce aircraft $\mathrm{CO} 2$ emissions by $75 \%$ per passenger kilometer, reduce noise by $65 \%$, reduce nitrogen oxides (NOx) by $90 \%$. This is one of the reasons why Rolls Royce devotes more than two-thirds of its R\&D budget to improving the environmental performance of its aircraft engines.

Figure 3 shows the actual and projected performance of Rolls Royce engines from before 2000, with the Trent 800 generation of engines, to 2050; by 2020, with the entry into the market of Advance engines, an improvement in efficiency of approximately $19 \%$ is forecast.

Figure 3: Performance of Rolls Royce engines.

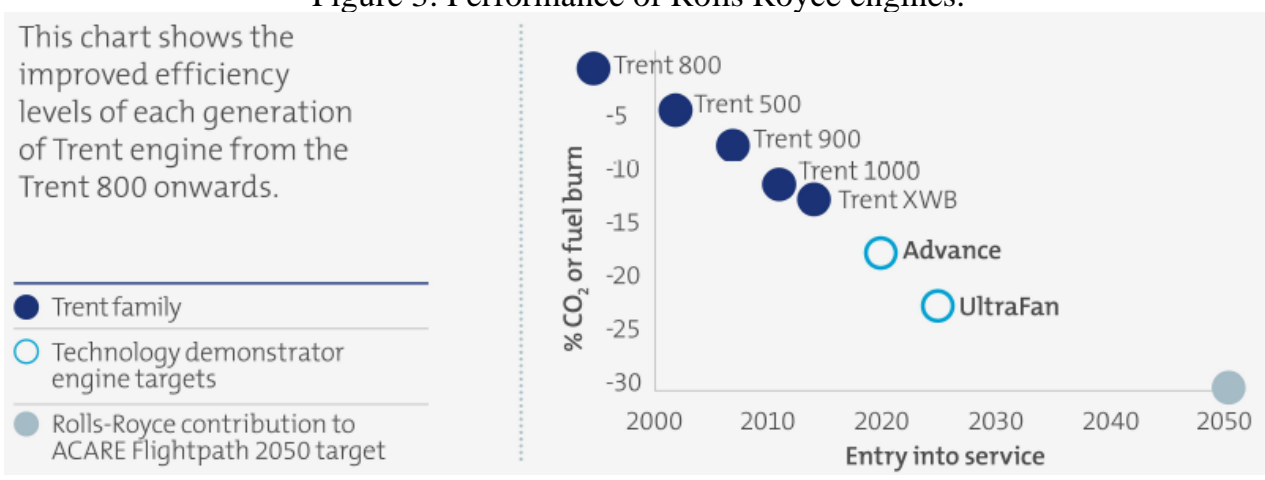

Source: Rolls Royce (2019) 
By 2025, UltraFan generation engines will be released that will have a $23 \%$ efficiency improvement over the Trent 800 . Fuel remains one of the highest operating costs for air carriers, as well as one of the largest contributing factors to the overall environmental impact of aviation. This drives up customer and societal demand for increasingly cleaner, quieter and more efficient products (Rolls Royce, 2019).

Alvarado, Godoy, Ibarbes, Ríos and Sánchez (2017) comment that radical changes have been seen in the structure of engines, such as the case of engines with GTF technology; they also highlight that the demands of the industry and society in general, have led to the creation of synergies between the main manufacturers to be able to develop engines with the best possible characteristics; in cooperation, each company contributes its best technology achieving a better product compared to individual work. Alvarado et al. also state that all construction companies have shown great efforts to improve performance in terms of environmental care, seeking to reduce emissions and noise.

\subsection{THE AIRLINES}

The Atmosfair index (2018) places airlines in a ranking from 0 to 100 points according to their $\mathrm{CO}_{2}$ efficiency, divided into short, medium and long-haul routes; in the overall ranking that includes all distances, Tui Airways appears in first place, followed by Latam Brazil and in third place China West Air. A common characteristic of the airlines that occupy the top positions is the high occupancy rate of their flights and the operation of updated, latest-generation, more technologically advanced and fuel-efficient aircraft, such as the Boeing 787-9 and the Airbus 350-900 and 320neo. Taking into consideration the environmental awareness of passengers, this index can serve different passengers who have the opportunity to include $\mathrm{CO}_{2}$ efficiency in the decision-making process during the purchase of an air ticket.

Another observation that can be made regarding this ranking is that most of the world's largest airlines do not appear in the top positions, for example: the world's largest airline, American Airlines, ranks 58th in the overall environmental efficiency index; Delta Airlines, the second largest fleet in the world, ranks 45th in the overall ranking; another large airline is United Airlines, which ranks 50th in the environmental efficiency ranking; Turkish Airlines is within the ten largest, but ranks 69th in the list of the most environmentally efficient. This situation may be due to the fact that the largest airlines also have the longest routes, which are the most polluting and have the greatest impact on the environment. It is important to remember that $80 \%$ of the sector's GHG emissions come from flights of more than 1,500 kilometers, where air transport of both people and cargo is the most efficient means (ATAG, 2018).

In the case of American Airlines (2018), the world's largest airline but ranked 58th in the Atmosfair index, the Environmental Management System (EMS) provides systemic guidance for developing 
instructions and directions for environmental regulations, including GHG emissions and hazardous waste treatment. The EMS is modeled on ISO 14001 and intimately related to the Safety Management System (SMS) approved by the Federal Aviation Administration (FAA).

American Airlines (2018) supports the ambitious goals set by IATA to mitigate CO2 emissions from air travel, particularly it has set the following goals: average fuel efficiency improvement of 1.5 percent per year from 2009 to 2020, carbon-free growth through a cap on aviation net CO2 emissions from 2020 and a reduction in aviation net CO2 emissions of 50 percent by 2050, relative to 2005 levels. Its targets are similar to those proposed by ICAO, and in some cases are even more demanding than those.

Figure 4: Savings in CO2 emissions due to operational adjustments by American Airlines.

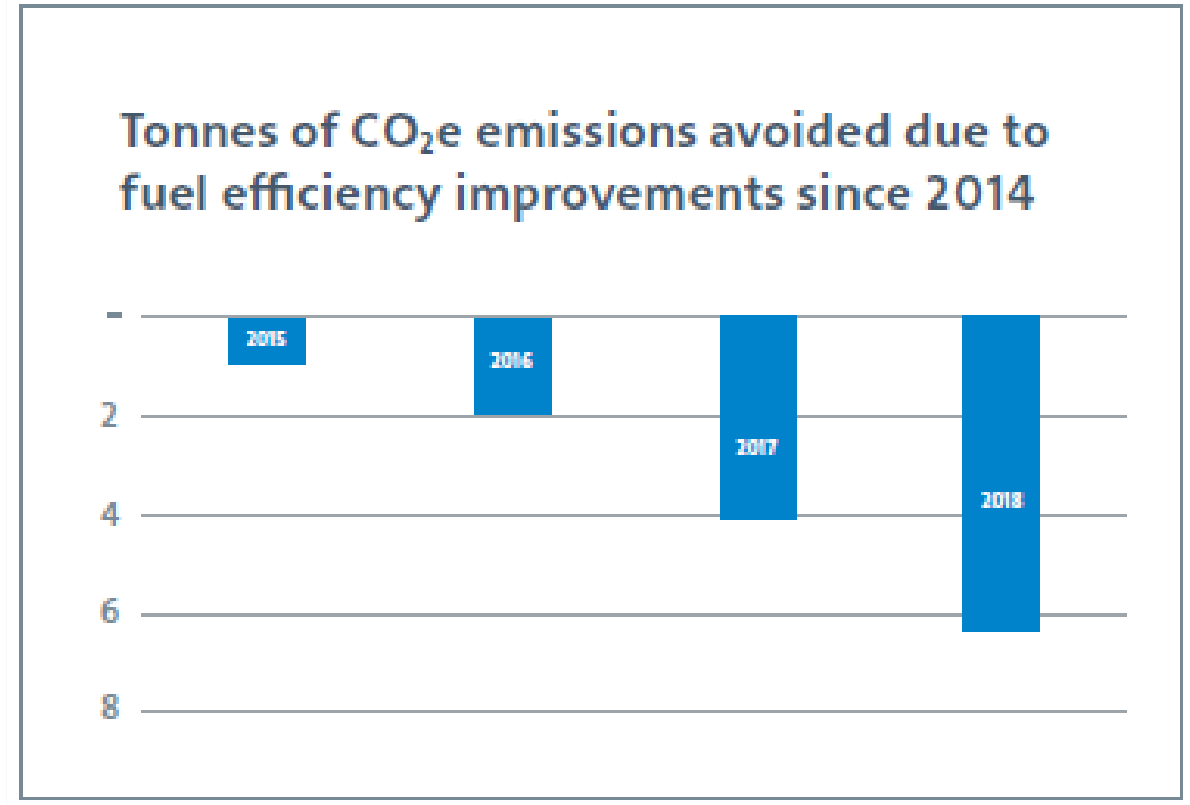

Million metric tonnes of $\mathrm{CO}_{2}$ e avoided

Source: American Airlines (2018)

Figure 4 shows the statistics regarding the number of tons of $\mathrm{CO} 2$ that American Airlines has stopped emitting into the atmosphere due to the efficiencies achieved in the use of fossil fuels, which were 6.4 million tons for 2018. According also to the Corporate Responsibility Report, in 2018, American Airlines emitted a total of 36.03 million tons of $\mathrm{CO} 2$, which represents a $17.78 \%$ savings in that period.

In the Latin American market is the airline Latam, which is among the most efficient in the world (Street, 2018), has a fleet renewal plan that allows it to be more efficient in emissions per passenger kilometer. In addition to this, in Peru and Colombia it has neutralized carbon emissions in ground operations, through local reforestation programs. The airline also has the Latam Fuel program, which manages all fuel saving initiatives, including operational and technological projects ranging from making operations more efficient to improving air traffic management and including structural developments in 
aircraft. The results of the implementation of these initiatives during 2015 correspond to fuel savings of more than 38 million gallons of fuel, which implies that more than 360 thousand tons of $\mathrm{CO} 2$ were no longer emitted (Latam, 2018).

\subsection{THE FUEL}

British Petroleum (BP) has a subsidiary in charge of the distillation and distribution of jet fuel, this is one of the main companies in charge of this business in the world and has also been involved in the development of ecological fuels; its proposal is called biojet. According to their studies and analysis, biofuel is the only alternative to jet fuel. As of the end of 2018, the industry as a whole has flown more than 100,000 flights on green fuel and demand is expected to continue to grow as the price differential between it and regular jet fuel decreases. Biojet is a jet fuel made from sustainable materials (solid household waste, recycled cooking oil, etc.) that reduces the amount of crude oil consumed and produces lower life-cycle $\mathrm{CO} 2$ emissions compared to conventional jet fuel. A blend of $50 \%$ biofuel and $50 \%$ hydrocarbon fuel can provide approximately 35\% reduction in $\mathrm{CO} 2$ emissions depending on the feedstock, production method and supply chain to the airport.

Biojet blended with regular fuel is approved for use in jet engines. No technical changes to aircraft are required and it is certified by aviation authorities. It is currently available at several airports in the Nordic countries. Air BP was the first operator to supply renewable jet fuel through an airport hydrant fueling system as part of normal operations at Oslo Airport since 2016 (BP,2019).

There is a variety of biofuels that come from different feedstocks or have different manufacturing processes. Green fuels can have higher or lower capacity to decrease greenhouse gas emission. Figure 5 shows the percentage reduction in GHG emissions when replacing fossil fuel with each of these types of biofuels; for example, a green fuel processed in the United States from corn grown in that country only reduces GHG emissions by $14 \%$, while a biofuel processed in Brazil from sugarcane can achieve a reduction of up to $88 \%$ in GHG emissions. These data do not include the effects due to land use change. 
Figure 5: GHG reductions from biofuels vs. fossil fuels

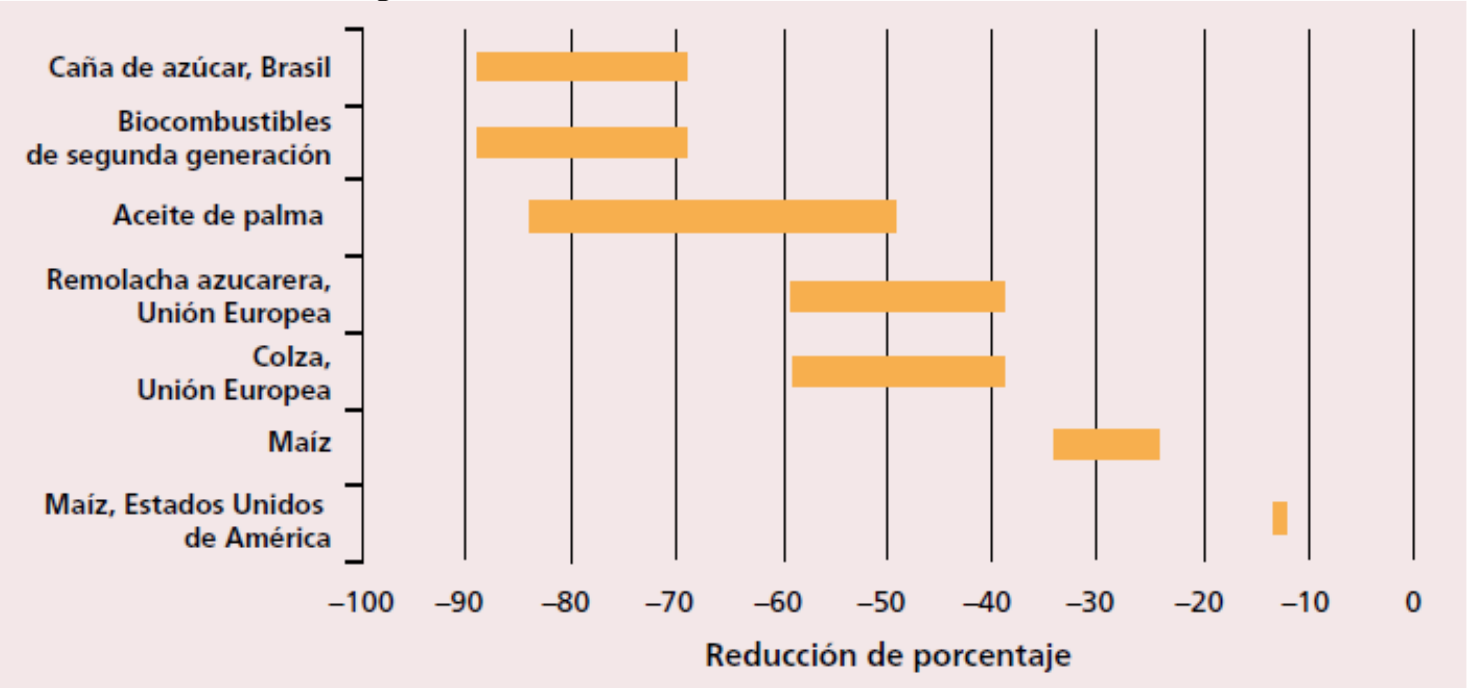

Source: FAO (2010).

Regarding biofuel production, Daynard and Daynard (2011) report that in 2008, $18 \%$ of sugarcane and $15 \%$ of the world's corn harvest was used for ethanol production, and $10 \%$ of the world's vegetable oil harvest was used for biodiesel production. These are high percentages of occupancy of arable land for the low percentages that biofuels have in the total amount of energy needed for air transport. In this regard, the Air Transport Action Group (ATAG, 2018) notes that in 2017, 14 million liters of biofuel were used for air transport compared to 341 billion liters of fossil fuel, a very low fraction indeed.

For the FAO High Level Panel of Experts (HLPE, 2013) the production of biofuels based on crops such as corn, sugar cane or vegetable oils, are related to increases in global food prices, this is why second or third generation biofuels have been developed, These are generated from non-edible or lignocellulosic biomass, such as agricultural by-products, forestry residues or urban waste, but production is still very low compared to the production of petroleum-based fuels.

In this order, Boeing together with Etihad Airways, Honeywell UOP and other scientific partner institutions in the United Arab Emirates, have made significant advances in perfecting sustainable biofuels for aviation based on desert plants irrigated with seawater, which are more efficient in biofuel production than other already known sources (Energiza, 2018). These projects involve companies and governments that, although they are hydrocarbon producers, understand the environmental need and economic potential of these projects. Another aspect that has not been fully studied is the performance of these biofuels, in this sense Mónico, Sandoval and Rodríguez (2017) compared the performance of jet engines using Jet A1 fuel, which is derived from hydrocarbons, with a mixture between this and fuel derived from oil palm; a decrease in engine thrust was observed as the proportion of the ecological fuel increases, this due to the lower calorific value of the latter. 


\subsection{AIRPORTS AND AIR TRAFFIC}

Airports, with their infrastructure and traffic management, also have an impact on the environment; it is important that they implement new technologies and innovations in energy, infrastructure design and traffic management so that they can be more efficient and competitive, and at the same time more environmentally friendly. An example of this is Cochin airport, the fourth busiest airport in India, which is internationally recognized for being the first airport in the world to be powered entirely by renewable energy. With more than 46,000 solar panels generating 13.1 megawatts (MW) of electricity to the airport facilities (Martinez, 2016).

With respect to airport infrastructure, Lui (2017) notes that "there are currently about 400 airports worldwide under construction or major expansion, or in advanced stages of planning with respect to related objectives" which means an increase of $25 \%$ over the previous year (2016) and the trend is to growth, influenced by the increase in demand for air transport services. This is why the manifest need to expand air transport capacity and that in the present and future it is managed through airports built or modernized on the basis of more efficient environmental policies and capacities. The progressive decrease in the costs of clean energies, which have become more and more competitive with respect to hydrocarbon energy, is in favor of this.

Alonso and Benito (2012) point out that "emissions that deteriorate air quality in the airport environment have their origin in aircraft movements, the operation of auxiliary equipment, the activities of terminals and other airport buildings, and the traffic of other modes of transport that access the airport to transport passengers and workers".

That is why recently, after three years of work by the Committee on Aviation Environmental Protection (CAEP/11), a series of recommendations to mitigate the impact of aviation on local air quality and global climate, including aircraft noise, were proposed in February 2019 in Montreal, with the assistance of 250 experts from 31 ICAO Member States and 10 international organizations. These recommendations include proposed amendments to Annex 16, Volumes I, II and III, including a recommendation on a new standard for emissions of non-volatile particulate matter (NVPM) from engines, which would be incorporated into Annex 16, Volume II (ICAO, 2019).

Regarding air traffic management (ATM), Graham (2011) assures that higher capacity and automated operating systems have been developed to handle the level of activities that are projected with the growth of traffic; initiatives such as NextGen in the United States, the Single European Sky ATM Research (SESAR) program in Europe and the Civil Aviation Reform Air Traffic Services (CARATS) programs in Japan have taken shape. This, together with various changes in airport operating procedures, will help aircraft to spend less time on the apron or taxiways waiting for clearance to take off, and will 
also reduce flight times, since one of the objectives of these latest-generation ATM systems is to modify air routes, make them more direct, and reduce the time that aircraft currently spend around airports waiting for clearance to land due to congestion.

Airbus also plays an important role in the SESAR project, which aims to shape the future of air transport and promote sustainable growth worldwide by developing air traffic management solutions. These air traffic management improvements could reduce $\mathrm{CO} 2$ emissions by $10 \%$ per flight (Airbus, 2018). All these projects and ideas are aligned with the ICAO proposal framed in the Global Air Navigation Plan 2016-2030, which motivates changes in technologies and procedures to generate greater capabilities and efficiencies in navigation (ICAO, 2016).

Finally, Juniac, Director General of IATA (2019), assures that airlines, manufacturers and airport operators know that legislation will become increasingly stringent in order to reduce GHG emissions, in fact, all the decisions that have been taken in recent times contribute to 15 of the 17 United Nations Sustainable Development Goals. To this end, ICAO together with IATA have promoted the Carbon Offsetting and Reduction Scheme for International Aviation (CORSIA); this is the first global carbon pricing instrument for an industrial sector. It will cap net $\mathrm{CO} 2$ emissions from international aviation at 2020 levels, i.e. carbon-free growth.

Seven of the largest aircraft and aero-engine manufacturers, Airbus, Boeing, Dassault, GE Aviation, Rolls Royce, Safran and United Technologies, according to EFE Green (2019), reaffirmed their responsibility to restrict aviation's impact on the environment. They assured that they are meeting the objectives they set more than a decade ago to limit the increase in $\mathrm{CO} 2$ emissions. For them, the three major challenges are: to continue technological innovation to reduce the consumption of hydrocarbon derivatives and thus their emissions, to strengthen the development and marketing of alternative fuels and, finally and transcendental, technological breakthroughs in the design of airplanes and their propulsion. The meeting also discussed the prospects of the electric airplane, recalling that Airbus is planning the first flight of its prototype in 2021, and that these aircrafts could be commercialized by 2030 .

\section{CONCLUSION}

Among the existing initiatives to reduce greenhouse gas emissions that are currently being developed, biofuels are an important option, but they are still at an early stage, and research and development must continue in this very promising area; meanwhile, improving the operability of the entire air transportation system and improving the most efficient designs of aircraft and their engines may be more profitable options in the short and medium term. 
The actors involved in air transport, governments, multilateral organizations, airlines, aircraft and engine manufacturers, airport operators, all agree that more radical changes must be made if the proposed CO2 emission targets for the year 2050 are to be met. To this end, all options must be explored and the research stages must be accelerated quickly in order to obtain tangible and real results in the shortest possible time. Biofuels are a good alternative, but alone it is not enough; therefore, other options of hydrogen-based fuels or aircraft working with electric batteries are being visualized, and others will surely emerge as potential solutions to this problem of climate change.

The aeronautical sector related to tourism has shown to have skills and spirit of coopetition within its related industries; with this it has achieved a safe and effective transportation system that connects all countries of the world, engine of human development. This, together with the most recent evidence of the grouping of different industries to research and develop solutions to climate change, suggests that there are sufficient commitments and capabilities to achieve the proposed goals and thus contribute to the sustainability of the planet.

There is alignment of objectives with air transport companies, since the lower the fuel consumption, the greater the financial benefit for the company and the lesser the impact on the environment. There is competition between airports; it is in the interest of each airport to attract more airlines that want to operate in its facilities, and to do so they must be as efficient as possible, providing airlines with shorter operations, where planes do not have to wait in line to take off or fly over the airport's surroundings, waiting for indications to be able to land. The more intelligent configuration of destinations, equipment to be used, schedules, etc., will produce significant savings in kilometers traveled and tons of $\mathrm{CO} 2$ emitted into the atmosphere, and will also promote greater economies for airlines. Likewise, air traffic management, aircraft taxing and routes used also have the potential for improvement to reduce fuel consumption. 


\section{REFERENCES}

AENA (2019). El transporte aéreo y el turismo en España. https://bit.ly/376S2vL

Airbus (2019). Innovating for sustainable solutions. https://bit.ly/31y9k3t

Airbus (2018). Anual Report: connecting the skies. https://n9.cl/bllm

Alvarado, B.; Godoy, M.; Ibarbes, P.; Ríos, I. y Sánchez, J. (2017). Comparación de motores P\&W, G.E y R.R. Universidad Técnica Federico Santa María. https://n9.cl/owdti

Alonso, G. y Benito, A. (2012). El impacto ambiental del transporte aéreo y las medidas para mitigarlo. En: "X Congreso de Ingeniería del Transporte (CIT2012)", 20/06/2012 - 22/06/2012, Granada, España. ISBN 978-84-338-5402-5. pp. 1-15

American Airlines (2017). Corporate Responsibility Report. Documento corporativo. https://n9.cl/3ql4

American Airlines (2018). Corporate Responsibility Report. Documento corporativo. https://n9.cl/30o3

ATAG (2018). Aviation - Benefits beyond borders, pág.7. https://n9.cl/borr

Atmosfair (2018). Atmosfair airlines index 2018. https://n9.cl/gxwb

Benjamin, R. (2010). El desafío de la sostenibilidad. Revista de la OACI, volumen $65 \mathrm{~N}^{\circ} 3$. https://n9.cl/yr4x

Boeing (2019). Informe medioambiental. Informe empresarial. https://n9.cl/k4jc

British Petroleum (2019). Environmental solutions for airlines. https://n9.cl/fmo5

Cordero, L. (1971). Turismo y Transporte Aéreo. IV Coloquio Internacional, Instituto del Transporte Aéreo, España. https://n9.cl/k0uz

Criado, M. (2019). Las estelas de los aviones afectan el clima más que sus emisiones de CO2. Reporte periodístico. https://n9.cl/ktsh

Daynard, K. y Daynard, T. (2011). What are the Effects of Biofuels and Bioproducts on the Environment, Crop and Food Prices and World Hunger? http://www.gfo.ca

EFE Verde (2019). La industria de aviones promete frenar su impacto ambiental. Reporte periodístico. https://n9.cl/5c0u

Espíndola, C., y Valderrama, J. (2012). Carbon Footprint. Part 1: Concepts, Estimation Methods and Methodological Complexities. Información tecnológica, 23(1), 163176. https://dx.doi.org/10.4067/S0718-07642012000100017

Energiza (2018). Boeing y sus socios en los Emiratos Árabes Unidos estudian producir biocombustibles a partir de plantas del desierto. https://n9.cl/syqk 
FAO (2010). Efectos de los biocombustibles en el medio ambiente. http://www.fao.org/3/i0100s/i0100s05.pdf

Faury, G. (2019). Minimising Invironmental Impact. Declaración de principios de Airbus. https://n9.cl/k55w

Garmendia, A.; Salvador, A.; Crespo, C. y Garmendia L. (2005). Evaluación de Impacto Ambiental. Pearson Prentice Hall. Madrid.

Graham (2011). Definición del futuro de la gestión del tráfico aéreo. Editado por OACI. Volumen 66, número 4. https://n9.cl/yj6p

HLPE (2013). Los biocombustibles y la seguridad alimentaria. Un informe del Grupo de alto nivel de expertos en seguridad alimentaria y nutrición del Comité de Seguridad Alimentaria Mundial, Roma. http://www.fao.org/3/a-i2952s.pdf

IATA (2018). Comunicado $\mathrm{N}^{\circ}$ 58: La aviación celebra una década de reducción de emisiones y reafirma su compromiso. https://n9.cl/sm1x

IATA (2019). Comunicado $\mathrm{N}^{\circ}$ 30: Aerolíneas exigen implementación del plan de compensación y reducción de carbono. https://n9.cl/gz9v1

Latam (2018). Sostenibilidad de cambio climático. https://n9.cl/vw4e

LEMCOTEC (2017). Construir un motor aeronáutico mejor. Resultado resumido. file:///C:/Users/jgarmendia/Downloads/CORDIS_result_147233_es.pdf

Liu, F. (2017). Seminario de la OACI para promover aeropuertos más verdes. Comunicado de prensa OACI. https://n9.cl/tmm7

Martelli, A. (2020). Environmental education action with urban tree planting in order to neutralize greenhouse gases. South Florida Journal of Development, 1(1), 2-10. https://doi.org/10.46932/sfjdv1n1001

Martínez, A. (2016). El único aeropuerto verde del mundo cumple un año. Artículo periodístico publicado en El País. https://n9.cl/3axj

McElroy, P. (2019). Boeing pilots the birth of biofuel for aviation's sustainable growth. Revista Innovation Quarterly, tercer trimestre 2019. https://n9.cl/661n

Mónico, L.; Sandoval, J. y Rodríguez, A. (2017). Estudio teórico sobre la influencia del uso de mezclas de biodiesel de aceite de palma con Jet A-1 en Motores a reacción”. Revista Ingeniería, vol. 22, no. 1, pp. 140-151. https://n9.cl/fm2c

OACI (2010). Declaración consolidada de las políticas y prácticas permanentes de la OACI relativas a la protección del medio ambiente - cambio climático. https://n9.cl/zxj7

OACI (2014). Informe anual del consejo de la OACI 2014. https://n9.cl/3gjby

OACI (2016). Plan Mundial de Navegación Aérea 2016-2030. https://n9.cl/309ft 
OACI (2019). Novedades en la OACI con respecto al medio ambiente. https://n9.cl/7nc2

OMT (2018). Conferencia mundial sobre el turismo y la energía del futuro: en busca de oportunidades de crecimiento con bajas emisiones de carbono. https://n9.cl/vr2e

ONU (2015). Cambio Climático. https://n9.cl/s4vzy

Rolls Royce (2019). Engeneering and Innovation. https://n9.cl/ns6e

Street, F. (2018). Las aerolíneas más amigables con el medio ambiente. Reportaje periodístico. https://n9.cl/3s $1 \mathrm{c}$

Vogeler, C. (2012). Transporte Aéreo y desarrollo turístico en América Latina y el Caribe. Revista Excelencia Magazine. Edición $\mathrm{N}^{\circ}$ 112. https://n9.cl/fezv

Yanitelli, M.; Pasch, V.; Mosconi, P.; Cabanellas, S.; Vazquez, J.; Rall, J.; Miyara, F. (2001). Manchas acústicas: ruido de aeropuertos. Cuartas Jornadas Internacionales Multidisciplinarias sobre Violencia Acústica. https://n9.cl/bkn9

Zarta, P. (2018). La sustentabilidad o sostenibilidad: un concepto poderoso para la humanidad. Tabula Rasa, (28), 409-423. https://n9.cl/pyi6e 